\title{
Community Perception on Public Primary Schools: Implications for Sustainable Fee Free Basic Education in Rorya District, Tanzania
}

\author{
Eliada Werungu Bina Tieng'o, $\mathrm{PhD}^{*}$ \\ Associate Registrar, University of Arusha, Tanzania
}

\begin{abstract}
"Corresponding author: williameliada@gmail.com
Abstract: Despite the involvement of community participation in various development projects over the years in Tanzania, little is known of its implications on sustainability of fee free basic education in rural public primary schools. A mixed method exploratory approach, informed by ecological systems theory, employed questionnaires, FGD and interview schedules to selected parents and School Management Committee members of public primary schools in Rorya District, Tanzania. The study focused on the value of public primary school education, advantages of Fee Free primary education, perceptions of parents and School Management Committee members on community participation and relationship between parent's perception on the value of public primary education and participation in project-based support to education. The respondents exhibited heterogeneous negative perceptions with a positive correlation between parent's perception on the value of public primary education and participation in project-based support to education $(r=.510, p=000<0.01)$. The larger majority $64.3 \%$ of parent respondents with grade 7 education was deemed a factor that influenced negative perception. The researcher recommends that the Government authorities need to impart community economic productivity skills; the District Authorities further need to conduct community awareness on the importance of participation. Finally, the Ministry of Education in collaboration with the other stakeholders should mobilize funds and sensitize communities on the value of primary education and the importance of their participation in community development programs to support education.
\end{abstract}

Key words: Basic Education, free education, community participation, Public schools, sustainable education, rural development.

\section{Introduction}

The exit of the Education for All (EFA) and the Millennium Development Goals (MDGs) initiatives ushered in the Sustainable Development Goals (SDGs) and the Education 2030 agenda. At the report of the post-2015 and the recommendations which were agreed upon by the world community, it was observed that most developing countries globally fell far short of achieving the EFA and the MDG education goals. Consequently, one of those recommendations deemed critical for achieving the expected SDGs outcomes by 2030 (UNESCO, 2015a) was cooperation of all the stakeholders, including the local community. The expected imminent outcomes include successful implementation of the 11 years of the Fee-Free Basic Education (FFBE) which in essence is a continuation of the EFA goals. The main objective of FFBE as the governments lifted the burden of fees was particularly to facilitate access to school particularly for children from rural poor households. One way to ensure sustainable implementation of FFBE policy is through resilient community participation approach.

Accordingly, UNDP (2004) points to the significance of rural areas as an investment and excess production location. This implies that rural areas are endowed to a certain extent with resources that could be mobilized to improve lives of the local people in each community. Pertaining to community participation strategy, UNDP (2016) perceive community-based initiated programs as fundamental techniques that would maintain human being wellness. The work of Oregon as cited in Turner (2012) claims that participation brings people together to create collective decisions that are contextual to their environment. Subsequently, it promotes people's ownership and control of their 
affairs. Hence, a critical need for rethinking global strategies for transformational universal human development and capacity building (UNESCO, 2016; 2015b).

Kimani and Kombo (2011) observed that international community is searching for new strategies through which beneficiaries will regenerate rural development. Community participation in development has therefore been regarded over the years as the most significant approach that contributes to self-improvement of communities. Further, it is envisioned as a typical approach that distributes responsibility and resources, involving the stakeholders (Phillips \& Pitman 2009; Schiele, 2005). It is the most outstanding model, according to Tan (2009) that provides the lasting change for individuals and communities in their localities. Bukenya and King (2012) under the World Bank Commission explored the interrelationship between critical contextual and approach-based factors as well as their effectiveness on shaping social accountability initiatives. They established that community inclusion in the administration of local assets enhanced supportability and structure.

A body of literature alludes to the concept and practice of community participation indicating how various parts of the world, for decades, have valued and used the strategy (Kieya, 2016). A study examined the use of various strategies to reinforce School Management Committee with the aim of strengthening community participation, accountability and ultimate learning. The findings showed that there was an increased engagement by education stakeholders when ties were strong between school and other parties rather than when there was only reinforcement of grants and training (Pradhan, et. al., 2013).

Another study seeking to determine the household level factors affecting school enrolment of boys and girls in relation with effect of community factors on school participation was conducted in Turkey using a multilevel analysis. In the study, the importance of community/context factors in explaining low school enrolment in the country immerged as significant. Spires, Shackleton and Cundill (2014) reiterate that community development projects are bound to succeed if they target the specific needs and resources (people, economy, and environment) critical to a given society. Likewise Lopez-Guzman, Parion, and Sanchez-Canizares (2011) tend to argue that critical for development projects sustainability are ecologic resources of the target areas and the importance of the role of the residents. A successful nation is one whose citizens are educated and are skillfully empowered to serve its development objectives. Hence, the quality of education system greatly influences the development trend of a nation. Consequently, well thought-out educational policy planning, formulation and implementation is a process that should be inclusive of all stakeholders in order to guarantee sustainability. Among the interested stakeholders, the local communities can ensure accountability and responsibility congruent to the consideration given to the contextual factors of the local communities.

The Tanzania Development Vision 2025 is to create a pool of skilled workforce. One way to achieve that is through Fee Free Basic Education policy that provides access to education for all children in Tanzania. Some literature has alluded to the consequence of physical setting as an essential aspect of school environment with implications to teaching and learning process. However, due to the school conditions and environmental related challenges such as textbook shortages, dilapidated classroom facilities, frayed school uniforms, as observed on the ground by the researcher, they are bound to influence the teaching and learning environment Bronfenbrenner (2005), Moos (1979) and Steele (1973). Given the intimidating school environment as described at the observed rural schools, the quality of education in public primary schools, would tend to be negatively prejudiced as the teaching and learning is equally influenced.

Furthermore, Oyunge (2015) alludes to similar sentiments where the conditions of school environment influences the primary schools in Moshi, Tanzania showed that despite the objectives of Tanzania government to provided access of education to all without discrimination, there was no proof that all the children enrolled were equally learning effectively. If this trend continues, the increased unskilled workforce will impede economic and human development as well as the national development plans. According to Oyunge (2015), when parents were asked to indicate if there was quality education in the primary school that their children attended, majority (70.0\%) said that quality education was not yet attained as the pupils completed primary education without ability in the reading, writing and arithmetic skills. The participants of the Focus Group Discussions (June 2018) repeatedly echoed the existence of some factors such as long distances, dilapidated school buildings, inadequate classroom space, shortage of textbooks and other learning materials that are fundamentally a hindrance to the learning process of 
their children. Further, Letea (May 15, 2018) concurs that student-teacher ratio exaggerated by the shortage of space and teachers, impacted the learning and consequently compromised the pupils' performance in a number of schools in Tanzania.

Specifically, the overarching objective of this study was to explore the community perceptions on public primary schools and their implications for participation in local-based projects for sustainable Fee Free Basic Education for optimum learning in Rorya District, Mara, Tanzania, using three major research questions.

\section{Related Literature and Studies}

This section presents both theoretical and empirical literature reviews on the issue of enhancing sustainability of basic education in public primary schools in Tanzania.

\section{Theoretical Underpinnings}

Theoretical Underpinnings for this study are derived from the Ecological Systems Theory, specifically, Bronfenbrenner's ecological system theory, also known as Human Ecology (Bronfenbrenner, 2005) which focuses on the relationship between the parts, rather than reducing an entity into its parts or elements. An organization is considered as a system having integrated parts that must be coordinated for efficiency and effectiveness.

Chikere and Nwoka (2015) acknowledge the importance of Ecological Systems Theory approaches in the modern day organizations which exist and operate in the highly changing environment. The study posits that it is crucial to think of an organization as a whole entity made up of parts that must work together to accomplish the objectives of the organization. In the case of this study, a school is an organization, of which the authors categorized the parts into two: technical (academic/professional) and social (Teachers/Parents/Community/Pupils) and perceived that if change occurred in one part of either category, it is bound to affect the whole organization.

Consequently, the implication for this study is that between the community and the school in the given community environment, if any change occurred, for example, on the teaching or learning process at school, it would certainly affect the community and vice versa. A change in some education policy, such as fee-free education, affects the community in one way or the other. Similarly, when the community reacts by participating or not participating in responding to the demands for education supply, the effect would be felt in the teaching and learning process at school. Further, Unlike Weber, Tailor and Fayol who viewed an organization as a closed system, the work of Ludwing Von Bertalanffy as cited in Chikere and Nwoka (2015) document that organizations were like living things that need to operate in an open system in order to survive.

\section{Community Participation}

There are better prospects for development in education when parents and schools work together. Empirical findings show that community involvement in education positively correlates with higher academic performance and school improvement (Rout, 2013). Involvement is enhanced when community perceive that schools satisfy their needs. As early as two decades ago, the World Bank and the International Monetary Funds (IMF) initiated intervening policies in hope to mitigate the economic instability that imposed devastating problems to most governments including those of the countries in the sub-Saharan Africa (Daven, 2008; Hakielimu, 2017).

Dongier et al. as cited in Mansuri and Rao (2004) described the significance of community participation as an instrument that increases, sustainability, efficiency and effectiveness, poverty reduction, more inclusive development, empowerment of the poor, and social capital. Also Berkes (2004) purports that when the objectives of community development project are marched with the objectives of education, and the perceived rural development meets the needs of the local community, then simultaneous development can be achieved. Moreover, it has been confirmed that social, economic and environment intervention activities of community-based development approaches have had positive impact among poor communities in the developing countries (Mansuri \& Rao, 2004).

The significance of community participation and education is seen in a reciprocate outcome resulting from the shared social environment as argued in the work of the First President of Tanzania, Mwalimu Julius Kambarage Nyerere cited in Lema, Omari, Rajani (2005) purporting that development and education are interrelated, and that the local citizens are the strength of poor countries in achieving appropriate development. Further, Lema et al. (2005) echo that "people are both the agents and the subject of their own development and also their education" (p.vi). According to Beider (2007), community participation at the local level, in policy 
and decision-making process, has been a crucial principle of government policy. Further, the importance of community participation in education decision-making process has long been emphasized as a sign of devolving power to the local level (Russell, Reimers, Mapp, Robotham, \& Warren, 2009).

\section{Methodology}

This section explains the research methodology used to guide the study.

\section{Research Design}

This study was done under the Mixed Approach. According to Bryman (2006) and Creswell (2014), the mixed methods research design is the appropriate strategy to explore the most relevant information to answer the problem under investigation. Moreover, mixed methods design has been known as one of the three major paradigms that have gained popularity among a number of researchers over the years as a method that provides for depth and understanding of issues of interest in a researcher's study (Johnson, Onwuegbuzie \& Turner, 2007). The quality of methodological 'pluralis or eclecticism' renders concurrent mixed methods research superior to the traditional qualitative or quantitative methods (Johnson \& Onwuegbuzie, 2004). Consequently, in this study, the researcher made use of the concurrent mixed methods research design in that, the researcher explored the collection of both qualitative and quantitative data which were the best way to understand the research problem in this study (Creswell and Creswell, 2018).

Kothari (2016) describes concurrent mixed method as a design that provides data collection and analysis by both quantitative and qualitative approaches. The study engaged the use of closed-ended questionnaires (numerical data) as well as face to face individual and focus group discussion in order to triangulate the data and increase its dependability and credibility and their interpretation (Zohrabi, 2013). A focus group is an informal discussion among a group of strategically selected individuals, between 6 and 12, as informants on a particular topic. It would involve a collective conversation or discussion. It provides the researcher an opportunity to probe critically to gain more in-depth information from the group to supplement the questionnaire surveys (Krueger \& Casey, 2009). Therefore, the face to face interviews with different participants both individual and focus groups, assisted the researcher to gain more understanding on the perceptions of the parents as well as that of the members of the School Management Committee on both the value of public primary school education and the advantages of free primary education, as well as the importance of participation in community projects to support primary education, in Rorya District, Mara, Tanzania. Further, it was the best way for the researcher to elicit the emerging information through the mixed design which otherwise would not be captured through a traditional approach.

\section{Validity and Reliability}

In order to enhance the content validity of the instruments, selected experts went through each item on the instrument against research questions. Their comments were integrated to ensure simplicity and clarity of all the questionnaire items. Triangulation process for qualitative data was also achieved during data collection. While there are four types of triangulation namely: data triangulation (from data sources), researcher triangulation (use of a research team) and theory triangulation (different theoretical perspectives on the same data), and methodological triangulation (use of different methods) (Baxter \& Jack 2008, Hancock \& Algozzine, 2006), the current study employed methodological triangulation where the researcher used different tools such as questionnaire, interview schedules for individuals and focus group discussions.

To ensure reliability, Cronbach's reliability coefficient was used to determine the internal consistency of the questionnaire (Mills \& Gay, 2016). While Cronbach's alpha coefficient of above 0.6 is considered acceptable (Creswell, 2008), the Cronbach's alpha coefficient was used to determine the internal consistence of the questionnaire items. Consequently, two items were deleted from the parents' questionnaire set as they seemed to lower the internal consistence. The items on both the parents' and the School Management Committee members' questionnaires yielded the Cronbach's alpha coefficient ranging between 0.7 and 0.85 recording a highly reliable coefficient.

\section{Statistical Treatment of Data}

The data was coded and analyzed using descriptive and inferential statistics through SPSS. Descriptive statistics established means and standard deviations in perceptions of the respondents, while Pearson Product -Moment correlation coefficient tested the relationships between variables. The following scale of mean score interpretation was applied on the research question number one and two: $1.00-1.49$ disagree (negative perception); $1.50-2.49$ tend to disagree (tend to be negative); $2.50-3.49$ tend to agree (tend to be positive); $3.50-4.00$ agree 
(positive perception). Further, the null hypothesis was tested on question three. The strength of correlations was interpreted as follows: Greater or Equal to $0.7=$ Strong Correlations; Greater or Equal to $0.5=$ Moderate Correlations and 0.49 and below $=$ Weak Correlations. Moreover, the FGD and interview data was thematically collated.

\section{Data Analysis and Interpretation}

This section presented the results of parents of the children and School Management Committee members of the selected public primary schools in Rorya District, Mara, Tanzania, on their perceptions of public primary schools as implication for participation in local-based projects for basic education. A total of 185 parents of the children enrolled and 75 School Management Committee members of the selected public primary schools were involved. While descriptive analysis was done to indicate the mean scores and standard deviation in the first two research questions, the inferential statistics analysis was fundamental to address the relationship among variables.

\section{Perception of Parents of Children Enrolled in Primary School}

Parental perception has been considered to be a noteworthy factor capable of influencing disposition positively or negatively toward schools. Subsequently, perception on the value of public primary schools is fundamental in parental participation in local-based projects for basic education sustainability in Tanzania. According to Swift-Morgan (2006) in his qualitative study of a relatively newly resettled community in a suburban areas in the United States of America, some of the parents expressed their sentiments with comments such as "We appreciate the importance of education; we built this school using the energy of the people here; we initiated it by ourselves; and education itself is development for this area." Consequently, when communities understand the value of education, they are self-driven to participate in education development. Therefore, in this study the researcher sought to establish the perception of the parents of public primary school children in Rorya District.

Research Question 1: What is the perception of the parents of primary school children in rural communities in Rorya District, Mara, Tanzania on a) the value of public primary school education and $b$ ) the advantage of free primary education?

The data in Table 1 generally revealed that there is no value of primary school education in Rorya District as per the mean rating and standard deviation $(\mathrm{M}=1.54 ; \mathrm{SD}=.665)$. The parents tend to disagree that through public primary school education, every single child (boy or girl) will be able to complete primary school education and that completing the seven years of primary school education provides children with competencies in basic skills of reading, writing, and arithmetic.

Table 1: Perceptions on the Value of Primary School Education

\begin{tabular}{|c|c|c|c|}
\hline $\mathbf{S N}$ & Item in the Questionnaire & Mean & Std. Dev \\
\hline 1. & Every single child (boy or girl) should be able to complete primary school education. & 1.24 & .693 \\
\hline 2. & $\begin{array}{l}\text { Completing the seven years of primary school education provides children with } \\
\text { competencies in basic skills of reading, writing, and arithmetic. }\end{array}$ & 1.42 & .837 \\
\hline 3. & $\begin{array}{l}\text { Primary school education is the foundation for gaining basic knowledge that leads to } \\
\text { the betterment of a child. }\end{array}$ & 1.34 & .844 \\
\hline 4. & $\begin{array}{l}\text { Education earned during the seven years in primary school promotes individual's } \\
\text { creativity and innovativeness. }\end{array}$ & 1.65 & 1.068 \\
\hline 5. & Basic education increases individual's self-esteem and assertiveness. & 1.60 & .996 \\
\hline 6. & $\begin{array}{l}\text { The skills, attitudes, and knowledge that children gain in primary schools make children } \\
\text { successful in the future. }\end{array}$ & 1.51 & .979 \\
\hline 7. & $\begin{array}{l}\text { Children who complete the seven years of primary education tend to increase } \\
\text { productivity in the society. }\end{array}$ & 1.90 & 1.221 \\
\hline 8. & $\begin{array}{l}\text { The community's investment on primary school education will result to its economic } \\
\text { development. }\end{array}$ & 1.61 & 1.032 \\
\hline 9. & $\begin{array}{l}\text { Completion of primary education opens opportunities for the community to enjoy other } \\
\text { human rights. }\end{array}$ & 1.57 & 1.020 \\
\hline 10. & $\begin{array}{l}\text { The education that students get through primary school adds value to the community. } \\
\text { OVERAL SCORE }\end{array}$ & $\begin{array}{c}1.64 \\
1.549\end{array}$ & $\begin{array}{l}1.065 \\
.665\end{array}$ \\
\hline
\end{tabular}

With the means ranging from $(\mathrm{M}=1.24$ to 1.90$)$ which ranges from "disagree" to "tend to disagree," the parents further tend to disagree in all the ten 
statements. The standard deviation on most statements were greater ranging between (.837and 1.221), showing heterogeneity of responses in the following statements: "Education earned during the seven years in primary school promotes individual's creativity and innovativeness." $(\mathrm{M}=1.65 ; \mathrm{SD}=$ 1.06). "Basic education increases individual's selfesteem and assertiveness" (M=1.60; $\mathrm{SD}=.99)$, "the skills, attitudes and knowledge that children gain in primary schools make children successful in the future" ( $\mathrm{M}=1.51 ; \mathrm{SD}=.97)$, "children who complete the seven years of primary education tend to increase productivity in the society" $(\mathrm{M}=1.90 ; \mathrm{SD}=$ 1.22), "the community's investment on primary school education will result to its economic development" $(\mathrm{M}=1.61 ; \mathrm{SD}=1.03)$, "completion of primary education opens opportunities for the community to enjoy other human rights" ( $\mathrm{M}=1.57$; $\mathrm{SD}=1.02$ ) and "the education that students get through primary school adds value to the community" $(\mathrm{M}=1.64 ; \mathrm{SD}=1.06)$. This signifies that there is variability in perception among the respondents of public primary schools in Rorya District regarding the value of primary education. While there are potential values that are obtained in the primary school education, it is important to note that there is room for adding value to public primary school education in Rorya District.

Further, heterogeneity in responses are in agreement with the argument of Gibbs, as cited in Robinson and Green (2011) that public school educate individuals, but the benefit spills over to the labor force of the local and state economy. While the parents of children attending the public primary schools may be aware of the need to provide valuable education for their children, they are of the perception that primary education obtained in Rorya District public primary schools lacks value enough to impact their community.

Nevertheless, the findings can be explained further by John (2009) in a comparative study of public against private primary schools which eludes the qualities suitable and preferred school environment for learning. The private primary schools, unlike the public primary schools were found to be rich in motivated, quality, skillful and committed teachers, resources and facilities, child centered teaching methods, responsible parents and good learning environment. Accordingly, the researcher observed that the selected schools of Rorya District were far short of such qualities or incentives. The words of Mwalimu Julius K. Nyerere in Lema, Omari and Rajan (2005) allude to the fact that community needs to target on in order to better improve the education delivery of these schools; hence, to add value of public primary schools. Further, the primary school education provided in Rorya public primary schools need more improvement to facilitate education and quality of delivery to enhance the quality of learning environment and amount of learning that take place. Similarly, the following interview participants' comments support the above rating scores in that "...Teachers are not teaching." "...There is scarcity of teaching and learning materials and children don't have books." "...There is shortage of qualified teachers and the teacher student ration is not according to the expected standards." In this respect, Makomelelo and Swai (2013) validate the concerns verbalized by some participants in agreement with the observation that the Tanzanian public primary schools for the past two decades experienced a substantial number of school age children who lacked basic literacy and numeracy skills.

These findings imply that parents of the children enrolled in public primary schools in Rorya District when rated according to the ten items, do not value the kind of primary school education that their children receive. The sentiments of the Focus Group Discussions of parents and the Ward Education Coordinators (WECs) as well as the open-ended information for the parents were repeatedly expressed in various indicators as several participants said:

".... Teachers are not teaching well."

".... Children are not learning."

".... Parents and teachers have no good relationship."

".... There are no books in schools."

".... Schools no longer call parents to school on closing day to give pupils' reports cards."

"....Poor infrastructure at school."

"....Teachers are not committed to their work."

"....Children stay hungry at school."

"....There is conflict between teachers and community."

"....Classrooms are very few while pupils are over enrolled."

"....There are very few teachers."

"....Some children sit on the floor."

In addition to the participants' expressions, the researcher's observations confirmed that most of the concerns were genuine, as revealed by the dilapidated classroom conditions, over used facilities with the number of pupils, and pupil-teacher ratio which was out of proportion. According to Letea (May 15, 2018), in most primary schools in the United Republic of Tanzania, teachers managed 
more pupils than acceptable standard of (PTR-1:40). These sentiments justify the perception of the participants on the value of primary school education. The school environment as expressed and observed by the participants and the researcher, renders the public primary school incapable to facilitate the workforce for Tanzania Development Vision (TDV) 2025 with the theme "Nurturing Industrialization for Economic Transformation and Human Development" (Ministry of Finance and Planning of The United Republic of Tanzania, 2016). Oyunge (2015) in support these findings argues that while the aim of Tanzania Government Free Basic Education Policy is to improve quality, evidence for provision of quality education for all children is obscure as many classes are overcrowded. Further, the findings of John (2009) support findings of this study that private primary schools provided better quality education when compared to government or public primary schools.

More response to this problem can be traced in some of the participants' comment that "... They want the government to make their school nice like private schools. "Mwaura and Ngugi (2014) reiterate that skills and knowledge that an individual is able to acquire through formal or informal education are necessary for carrying out tasks and thus enhance work performance. Further, UNDP (2015) concurs that primary education should enhance productivity and creativity among the least educated. It is also important to note a possibility that the discord between the parents' perceptions and the fact on the value of education could be lack of awareness on the part of the parents. Furthermore, whereas the level of education of most parents under investigation is grade 7 which constitute a bigger majority $64.3 \%$, this situation could have an influence on the perception level of the respondents.
Finally, the findings in this study are verified by the World Bank (2013) observations that despite the significant gains in universal enrollment $90 \%$ in the low and middle income countries by 2011 , learning remains far low. UNESCO (2015a) reiterate that up to one third of all children Worldwide could not read or write; 130 or 250 millions who could neither read nor write had been in school for a period of four years; while more than $50 \%$ of the estimated 2 million shortage of teachers will be in Sub-Saharan Africa.

\section{Perception on the Advantages of Free Primary Education}

The researcher, further, sought to establish the perception of the parents on the advantages of free primary education. To achieve this objective, the respondents were presented with eight items for perception on the advantages of free primary education which they rated accordingly on the basis of the aforementioned scale of interpretation:

Table 2 presents the overall mean rating of $(\mathrm{M}=$ 1.71; $\mathrm{SD}=.62$ ). This implies that the parents tend to disagree that there are advantages in free primary education with low standard deviation meaning there is strong homogeneity of responses. This homogeneity of response indicates that the parents equally perceived that they have not realized the benefits of free primary education.

The parents tend to disagree on all the eight statements indicating that they see no advantages of free primary education in Rorya District with means ranging from 1.36 to 2.14 ).

Table 2: Perceptions on the Advantages of Free Primary Education

\begin{tabular}{|c|c|c|c|}
\hline SN & Item in the Questionnaire & Mean & Std. Dev \\
\hline 1. & Free education has eased the financial burden of education in public primary schools. & 1.45 & 1.146 \\
\hline 2. & All enrolled children have remained in school since the beginning of Free Education in & 160 & 1023 \\
\hline 3. & The government capitation and grants adequately cover the demands for education. & 2.14 & 1.215 \\
\hline 4. & $\begin{array}{l}\text { Free education will be sustainable this time due to the current government's } \\
\text { determination and support. }\end{array}$ & 1.56 & .926 \\
\hline 5. & $\begin{array}{l}\text { Every child has equal opportunity to quantity and quality of education due to the free } \\
\text { primary education. }\end{array}$ & 1.36 & .816 \\
\hline 6. & $\begin{array}{l}\text { Free education has raised the prospects of getting all children to complete primary } \\
\text { education. }\end{array}$ & 1.45 & .766 \\
\hline 7. & $\begin{array}{l}\text { Children in rural public primary schools currently enjoy the benefits of equal rights to } \\
\text { education due to free primary education. }\end{array}$ & 2.11 & 1.255 \\
\hline 8. & $\begin{array}{l}\text { Quality of teaching and learning has declined with free education implementation. } \\
\text { OVERAL SCORE }\end{array}$ & $\begin{array}{c}2.06 \\
1.716\end{array}$ & $\begin{array}{l}1.164 \\
.622\end{array}$ \\
\hline
\end{tabular}


Particularly, the mean scores indicate that majority of respondents tend to disagree with the statements presented that "free education has eased the financial burden of education in public primary schools." $(\mathrm{M}=1.45 ; \mathrm{SD}=1.14)$, every child has equal opportunity to quantity and quality of education due to the free primary education" $(\mathrm{M}=$ 1.36; $\mathrm{SD}=1.81$ ) and that "free education has raised the prospects of getting all children to complete primary education" $(\mathrm{M}=1.45 \mathrm{SD}=.766)$, "all enrolled children have remained in school since the beginning of Fee-Free Education in 2016" (M=1.60; $\mathrm{SD}=1.02)$, "the government capitation and grants adequately cover the demands for education" $(\mathrm{M}=2.14 ; \mathrm{SD}=1.21)$, "fee-Free education will be sustainable this time due to the current government's determination and support $(\mathrm{M}=1.56 ; \mathrm{SD}=.92)$, "children in rural public primary schools currently enjoy the benefits of equal rights to education due to free primary education." ( $\mathrm{M}=2.11 ; \mathrm{SD}=1.25)$; and "Quality of teaching and learning has declined with free education implementation" $(\mathrm{M}=2.06 ; \mathrm{SD}=$ 1.16).

The respondents tended to disagree in their perceptions with high standard deviation scores showing heterogeneity of the responses. The heterogeneity in perception signifies the high disparity of scores from the mean and hence the responses are highly divergent in their perception. These findings imply that the fee free primary education in Rorya District is variably perceived by the parents, some seeing advantages while others not seeing the advantages. The heterogeneity responses further signify that while there are some disadvantages seen in free basic education, there are potential advantages that are not currently realized by some parents in free education. It is therefore important that much is done to educate parents on the value of free education in Rorya District

According to the interview with participants, the free primary education has brought more damages among the public schools in Rorya. Several participants echoed their sentiments as follows: "...The capitation money is not enough. This sentiment justifies the FFBE policy plan and the very reason why the government, for the sake of sustainability, required the parents to participate in supporting their children's education through cost sharing in terms of following up on attendance and pupil's academic progress; purchasing the learning materials, pens, pencils, text and exercise books; to cooperate with the school administration on planning lunch meals within the contextual setting; to ensure availability of transport fare for school pupils to and from school; and to follow up on absenteeism and academic progress, and construction (URT,2015a; 2015b \& 2016).

Other respondents revealed that "there are too many pupils and the teachers cannot teach them; books are scarce." In harmony with these findings, Oyunge (2016) in his study found that lack of inclusiveness; excessive class enrollment and hostile environment interfered with the intended outcomes. For parents to enjoy the advantages of education their children must prove they are acquiring knowledge, skills and attitudes expected from school; and that the educational objectives such as ability to read, write and speak are evident in children when they came home.

These findings confirm the researcher's observation whereby the respondents, across the schools visited, complained concerning the introduction of free primary education, despite the monthly capitation of TShs.500, per child, that the government disburses. Furthermore, there was a general view among people that parents feel the government has denied them to perform their rightful role for their children's education. "... We are not allowed to contribute any money to the school."

The researcher further observed that the government had positive intensions to restrict any kind of demand for cash at school level, but the community can contribute in kind or manpower and that some ill motives from some few citizens intended to distort the government's intent and what is actually being experienced. This observation is supported by the parents' disagreement on the statement "Quality of teaching and learning has declined with free education implementation" $(\mathrm{M}=2.06 ; \mathrm{SD}=1.16)$ "Yet, during the interviews with Focus Group Discussions, the participants were in unison to record their disagreement that "... Free education has eased the financial burden of education in public primary schools."

Nishimura et al. (2009) in a comparative study of Ghana, Malawi, Kenya and Uganda it emerged that "a general observation of schools indicate that parents hold more negative and passive attitudes in most schools" (p.155). Parents in this study, like the parents in Malawi (Nishimura et al., 2009) held negative perception on the statement "Every child has equal opportunity to quantity and quality of education due to the free primary education." This perception is supported by the situation observed by the researcher during data collection both among the Focus Discussion Groups participants and the SMC's 
interviews where it was clear that parents held negative perception toward the schools due to scarcity of books and teaching and learning materials. However, it was also clear that parents including other stakeholders lacked awareness of the role the parents to facilitate the FFBE policy, due to lack of proper dissemination of information.

Research question two: What are the perceptions of a) parents of primary school children and b) School Management Committee members in rural communities in Rorya District, Mara, Tanzania on the importance of participation in projects to support primary education?

Parents' Perceptions on the Importance of Community Participation in Community Development Programs for Education

In the first part of research question two, the researcher sought to establish the perceptions of parents of primary school children on the importance of community participation in projects to support primary education. To achieve this, nine items were presented to the respondents for mean score rating.

Therefore, Table 3 presents the responses on the importance of community participation in community development programs for education in Rorya District, as indicated at the overall mean $(\mathrm{M}=1.42$; $\mathrm{SD}=.49)$ which denotes "disagreement." The low standard deviation indicates the homogeneity of responses. This homogeneity signifies that the parents' perception is highly concentrated around the mean, implying consistency in the respondents' perceptions on the importance of community participation in community development programs for education for public primary schools in Rorya District.

Table 3: Parents' Perceptions on the Importance of Community Participation in Community Development

\begin{tabular}{|c|c|c|c|}
\hline $\mathbf{S N}$ & Item in the Questionnaire & Mean & Std. Dev \\
\hline 1. & $\begin{array}{l}\text { Community participation in programs to support education will increase a sense of } \\
\text { ownership and accountability. }\end{array}$ & 1.36 & .775 \\
\hline 2. & $\begin{array}{l}\text { If community members participated actively, it would benefit the school and the } \\
\text { community. }\end{array}$ & 1.36 & .761 \\
\hline 3. & $\begin{array}{l}\text { Participating in the programs will ensure equal distribution of resources to improve the } \\
\text { community life. }\end{array}$ & 1.43 & .812 \\
\hline 4. & Community participation in programs will increase the sustainability in basic education. & 1.36 & .816 \\
\hline 5. & The programs to support education may empower the poor communities. & 1.34 & .784 \\
\hline 6. & $\begin{array}{l}\text { I take responsibility and accountability for my community and school as I participate in } \\
\text { programs to support education. }\end{array}$ & 1.46 & .866 \\
\hline 7. & $\begin{array}{l}\text { Programs that are responsive to local community needs while targeting the educational } \\
\text { demands can sustain basic education. }\end{array}$ & 1.33 & .711 \\
\hline 8. & $\begin{array}{l}\text { Community participation to support education through cost-sharing will meet the } \\
\text { demands of education. }\end{array}$ & 1.66 & 1.009 \\
\hline 9. & $\begin{array}{l}\text { Participation in project-based programs to support education will increase social capital } \\
\text { in solving the community's education demands. }\end{array}$ & 1.44 & .826 \\
\hline & OVERALL SCORE & 1.416 & .499 \\
\hline
\end{tabular}

The mean scores distributions of the eight item by item range from ( $\mathrm{M}=1.33$ to 1.66$)$ denoting "Disagree" or "Tend to disagree" meaning the respondents disagree with all the eight items stated as follows: "Community participation in programs to support education will increase a sense of ownership and accountability" (M=1.36; SD = .77) "If community members participated actively, it would benefit the school and the community" ( $M=1.36$; SD = .76)" "Participating in the programs will ensure equal distribution of resources to improve the community life" ( $\mathrm{M}=1.43$; $\mathrm{SD}=.81)$ "Community participation in programs will increase the sustainability in basic education" ( $\mathrm{M}=1.36$; SD $=.81)$ " "The programs to support education may empower the poor communities" $(\mathrm{M}=1.34 ; \mathrm{SD}=.78$
" "I take responsibility and accountability for my community and school as I participate in programs to support education" $(\mathrm{M}=1.46 ; \mathrm{SD}=.86)$ " "Programs that are responsive to local community needs while targeting the educational demands can sustain basic education" $(\mathrm{M}=1.33 ; \mathrm{SD}=.71)$ "Participation in project-based programs to support education will increase social capital in solving the community's education demands" $(\mathrm{M}=1.44$; $\mathrm{SD}=$ .82) "Community participation to support education through cost-sharing will meet the demands of education" $(\mathrm{M}=1.66 ; \mathrm{SD}=1.00)$

These findings can be interpreted that parents have no confidence in cost-sharing strategy to meet the demands of education for their children. Similar 
views were pointed out by participants in focus groups through the following statements:

"... The government promised to provide books."

“... The government should provide adequate teaching and learning materials to schools."

"... Education is now free. We are not supposed to give anything to education."

"... The government should improve the schools for our children."

"... Teachers are not friendly."

"... Parents have nothing to do with the schools. They belong to the government."

“... The contributions we ever made earlier for the identified school projects were never used for the intended purposes, and the projects were never completed."

"...The leaders have never given reports on the development of such projects and the meetings have never been convened for the past three years."

According to Hornby and Lafaele (2011) in line with community participation in education, "Parents who believe that their role is only to get children to school, which then takes over responsibility for their education, will not be willing to be actively involved ... either school-based or home-based" (p.39).

These findings imply that the parents whose children are enrolled in public primary schools in Rorya District are of perception that the idea of community participation in community development programs for education is not of importance and is bound to fail due to the experiences they have had in the past with school development programs. Such attempts were never fruitful. This view is verified by the utterances from some interviewed participants:

"...We have seen organizations come to bring ideas of projects to improve education for our children. The ideas sounded good, and the parents showed confidence in the viability of such project ideas, but when those people left they never came back again." "...The members have since been trained in a seminar, and they have been instructed exactly on what they should do; but when they realized there was no cash being given to them individually, they went underground."

Given the findings, Spires, Shackleton and Cundill (2014) contend that community development programs that are targeting needs and resources (people, economy, and environment) at a given society stand better chance to thrive. Bukenya and King (2012) further emphasize that local factors pay a major role that shape social accountability and warrant sustainability. Therefore, parents in Rorya District need to get mobilized to participate in community development projects for their children's quality education. It is imperative that parents get involved to change the conditions under which the children are enrolled in public primary schools.

While it is clear that the parents' view on joint effort has been distorted, deliberate initiatives towards satisfying the government's vision TDV 2025 is through joint effort by local communities, government agents, and school administration to improve the educational institutions is the sure direction to take. Therefore, it is obligatory to ensure that community involvement in development programs for education is viable and sustainable to produce the workforce that target the demands for industrialized economy of Tanzania.

\section{Committee Members' Perceptions on the Importance of Community Participation in Community Development Programs for Education}

In the second part of research question two, the researcher sought to establish the perceptions of school committee members on the importance of community participation in projects to support primary education. To achieve this, nine items were presented to the respondents for mean score rating. Table 4 presents the results on the ratings of the respondents for each of the statements.

The means scores of the first five outlined items show "Disagree" which means that the perspective of the respondents is negative: "Community participation in programs to support education will increase a sense of ownership and accountability" $(\mathrm{M}=1.31 ; \mathrm{SD}=.73)$ "If community members participated actively, it would benefit the school and the community" ( $\mathrm{M}=1.32 ; \mathrm{SD}=.73)$ "Community participation in programs will increase the sustainability in basic education" ( $=1.15 ; \mathrm{SD}=.45)$ "I take responsibility and accountability for my community and school as I participate in programs to support education" $(\mathrm{M}=1.37 ; \mathrm{SD}=.71)$ "Programs that are responsive to local community needs while targeting the educational demands can sustain basic education" $(\mathrm{M}=1.32 ; \mathrm{SD}=.66)$ Each one of these statements consolidates the negative perspective held by School committee members. They inclined to the capability of participation in community development programs for education this situation is bound to destroy the school completely as the community perceives no benefits of community involvement. 
Table 4: Committee Members' Perceptions on the Importance of Community Participation

\begin{tabular}{|c|c|c|c|}
\hline SN & Item in the Questionnaire & Mean & Std. Dev \\
\hline 1. & $\begin{array}{l}\text { Community participation in programs to support education will increase a sense of } \\
\text { ownership and accountability. }\end{array}$ & 1.31 & .735 \\
\hline 2. & $\begin{array}{l}\text { If community members participated actively, it would benefit the school and the } \\
\text { community. }\end{array}$ & 1.32 & .738 \\
\hline 3. & $\begin{array}{l}\text { Participating in the programs will ensure equal distribution of resources to improve the } \\
\text { community life. }\end{array}$ & 1.52 & .921 \\
\hline 4. & Community participation in programs will increase the sustainability in basic education. & 1.15 & .456 \\
\hline 5. & The programs to support education may empower the poor communities. & 1.67 & 1.057 \\
\hline 6. & $\begin{array}{l}\text { I take responsibility and accountability for my community and school as I participate in } \\
\text { programs to support education. }\end{array}$ & 1.37 & .712 \\
\hline 7. & $\begin{array}{l}\text { Programs that are responsive to local community needs while targeting the educational } \\
\text { demands can sustain basic education. }\end{array}$ & 1.32 & 661 \\
\hline 8. & $\begin{array}{l}\text { Community participation to support education through cost-sharing will meet the } \\
\text { demands of education. }\end{array}$ & 1.60 & 1.040 \\
\hline 9. & $\begin{array}{l}\text { Participation in project-based programs to support education will increase social capital } \\
\text { in solving the community's education demands. }\end{array}$ & 1.53 & .949 \\
\hline & OVERALL SCORE & 1.421 & .496 \\
\hline
\end{tabular}

The mean scores distribution of the last four items in table 4 show that the respondents' perspective "Tend to disagree" meaning their perspective tend to be negative in all the four sentences: "The programs to support education may empower the poor communities" ( $\mathrm{M}=1.67 ; \mathrm{SD}=1.05)$; "Community participation to support education through costsharing will meet the demands of education" $(\mathrm{M}=1.60 ; \mathrm{SD}=1.04)$ "Participation in projectbased programs to support education will increase social capital in solving the community's education demands" $(\mathrm{M}=1.53 ; \mathrm{SD}=.94)$ "Participating in the programs will ensure equal distribution of resources to improve the community life" $(\mathrm{M}=1.52 ; \mathrm{SD}=.92)$

The results reveal that the perception of members of the School Management Committee is negative on all the four items with very high standard deviations. High standard deviation indicates that the members are not in harmony in the way they view they each of these items. These findings suggest that these members have no positive attitude toward the importance of community involvement. According to Nishimura et al. (2009), financial and administrative constraints together are likely to affect the School Management Committee members' perception on provision of primary education. Lack of financial resources, for example, could attribute to a tendency of negative perception on cost sharing and so forth. Therefore, there is some likelihood that the perception of school committee members is affected by the existing financial and administrative constraints.

Yamada (2014) alludes to the assumption of the role of SMCs as a central tool to improve both access to and quality of education; consequently, the driver of the sense of ownership that will encourage the local residents and school administration to contribute effectively and efficiently toward school administration. The results imply that the SMCs members are not optimistic about achieving their primary role. On the contrary, the SMCs should be enthusiastic about facilitating a meaningful relationship between the community and the school's administration, particularly among public primary schools in Rorya District.

Several members of the Focus Group Discussion expressed that "...We do not have platform where to report our (parents) concerns about education for our children." this suggests a possibility that some parents in various communities are interested to participate in improvement of the schools, but the effort to achieve that would be thwarted at some point. Others said, “... Some members of the SMCs are illiterate." Meaning such committee members have no capability of following, understanding, and challenging the proceedings for the interest of the parents and the development of the school. The rest said, "...There is no way the concerns of the parent are made known to the school administration." This suggests that the community representatives in the committee either are not aware of their responsibilities or they compromise their responsibility by not conveying properly the parents' concerns to school administration

These findings imply that the members of the school management committee manifest that community participation is not important. The researcher also observed very dirty and dilapidated school environment and building structures in most schools. This suggests the possibility that the parents are removed completely from the welfare of the school maintenance. This is contrary to the UNDP (2016)'s 
suggestion community-based initiated programs are fundamental to maintain the welfare of the schools.

\section{Relationship between Perceptions on the Value of Primary School Education and Importance of Community Participation in Community Development Programs for Education}

On the third research question, the researcher sought to establish relationship in the parents' perceptions as follows:

Research Question Three: Is there a significant relationship between the parents' perceptions on the value of public primary school education and perceptions on the importance of participation in project-based support to education?

In order to answer the third research question, the researcher formulated the following null hypothesis: "There is no significant relationship between the parents' perceptions on the value of public primary school education and perceptions on the importance of participation in project-based support to education." To test for the relationship between the two perceptions, the Pearson's correlation coefficient was used.

Table 5: Correlation between Perception on the Value of Primary School Education and Importance of Community Participation

\begin{tabular}{|c|c|c|}
\hline VARIABLE & & $\begin{array}{l}\text { Importance of community participation in } \\
\text { community development programs for education }\end{array}$ \\
\hline \multirow{3}{*}{$\begin{array}{l}\text { Perception on the value of primary } \\
\text { school education }\end{array}$} & Pearson Correlation & $.510^{* * *}$ \\
\hline & Sig. (2-tailed) & .000 \\
\hline & $\mathrm{N}$ & 185 \\
\hline
\end{tabular}

**. Correlation is significant at the 0.01 level (2-tailed)

The correlation coefficient $(r=.510, p=000<0.01)$ shown on Table 5 reveals that there is a significant positive yet weak relationship between the parents' perceptions on the value of public primary school education and the perceptions on the importance of community participation in community development programs for education at .000 which is less than the critical value. This means those who value primary education tend to engage in community participation in community development programs.

Therefore, null hypothesis was rejected. Banerji, Berry and Shotland (2014) argue that low education is often considered as a result of a low quality education system, characterized by poor schools infrastructures, limited materials, inappropriate pedagogy and low quality teachers. The result is manifested in the utterances drawn from the Focus Group interviews such as "Children are not learning these days," "Parents have disowned the schools," "Teachers are not teaching to mean they are not well qualified." Such statements show that the parents have negative perspective toward primary schools. While Lindsjo (2017) observed that parents have a sense of the value of primary education since they believe it is the only way to change their household life from poverty to wealthy, on the other hand, they realize that with the current situation of inclusivity and the poor environment of the school condition their children may not be able to acquire the quality education. Such prevailing situation which does not promise the acquisition of education sought for their children, tend to intensify negative perceptions. On a similar note, in a comparative study between the private primary schools and government primary schools of Tanzania in some selected regions, John (2009) showed the private primary schools unlike government primary schools had characteristics: responsible parents, quality teaching and learning environment, skillful and committed teachers, availability of resources and good learning environment, meaning that these factors influenced positively the perceptions of parents as they saw the value of education.

Consequently, it is imperative, as previously seen the parents' perception tends to be negative on the value of primary school education. Given the prevailing perspective of parents' perception on the value of primary school education, it equally influences the perception in community development programs for education where by the participants perception will tend to be negative too.

\section{Conclusions and Recommendations}


This section gives conclusions derived from results of the study and then gives corresponding recommendations.

\section{Conclusions}

Based on analysis of data and discussion of findings regarding perception of the community on free basic education and their participation, it is concluded that: The parents showed no interest in supporting their children's education for fear of wasting finances. They testified that most of the children who attended the local schools completed without mastery of the 3Rs. Hence, lack understanding of the aims of primary education. As obviously described by the bigger majority $64.3 \%$ being only grade 7 , this may have influenced the negative perception.

Respondents perceived that community participation was not important, meaning community participation was not necessary. It is possible that due to lack of understanding, they remained negligent and ignorant about it.

There was a positive yet weak significant relationship between the variables in that, the value of primary school education was found to have positive significant influence on the perception on the importance of community participation in community development programs for education ( $p$ $<.05)$. So the null hypothesis was rejected.

\section{Recommendations}

Based on conclusions above, the researcher gives the following recommendations:

The Government authorities should impart to the community diverse economic productivity skills.

The District authorities, particularly the District Executive Director and the District Education Officer should conduct community awareness on the importance of their participation.

The Ministry of Education in collaboration with the other stakeholders should mobilize funds and sensitize communities on the value of primary education and the importance of their participation in community development programs to support education.

\section{Reference}

Banerji, R., Berry, J., \& Shotland, M. (2014). The impact of mother literacy and participation programs: Evidence from a randomized evaluation in India. American Economic Journal: Applied Economics, 9(4), 303-337.
Baxter, P. \& Jack, S. (2008). Qualitative Case Study Methodology: Study Design and Implementation for Novice Researchers. The Qualitative Report, 13(4), 544-559. doi/10.2174/1874434600802010058

Beider, H. (2007). Neighbourhood renewal and housing markets: Community engagement in the US and UK, (ed). Oxford: Blackwell

Berkes, F. (2004). Rethinking community-based conservation. Journal of Conservation Biology, 18 (3), 621-630.

Bukenya, B. \& King, S. (2012). The contextual factors that shape social accountability. The University of Manchester, UK: Institute for Development Policy and Management School of Environment and Development.

Bronfenbrenner, U. (2005). Making human beings human: Bioecological perspective on human development. Thousand Oaks, CA: Sage Publications, Inc.

Bryman, A. (2006). Integrating quantitative and qualitative research: How is it done? Journal of Qualitative Research, 6(1), 97-113.

Chikere, C. C. \& Nwoka, J. (2015). The systems theory of management in modern day organization. A study of Aldgate Congress Resort Limited. Port Harcourt International Journal of Scientific Research.

Creswell, J. W. \& Creswell, J. D. (2018). Research design: Qualitative, quantitative, and mixed methods approaches $\left(5^{\text {th }}\right.$ ed.). Los Angeles: SAGE.

Creswell, J. W. (2014). Research design: Qualitative, quantitative, and mixed methods approaches (4th ed.). California: SAGE Publications. Retrieved from http://www.amazon.com/Research-DesignQualitative-Quantitative-Approaches

Creswell, J. W. (2008). Educational research: Planning, conducting and evaluating Daven, J. (2008). Free Primary Education in Tanzania? A case study on costs and accessibility of primary education in Babati 
town. Copenhagen: Sodertorn University College.

Daven, J. (2008). Free Primary Education in Tanzania? A case study on costs and accessibility of primary education in Babati town. Copenhagen: Sodertorn University College.

Hakielimu (2017). The impact of the implementation of fee-free education policy on basic education in Tanzania: A qualitative study. Dar es Salaam, Tanzania: Hakielimu.

Hancock, D. R. \& Algozzine, B. (2006). Doing Case Study Research: A Practical Guide for Beginning Researchers. New York: Teachers College Press.

Hornby, G. \& Lafaele, R. (2011). Barriers to parental involvement in education: An explanatory model. Educational Review, 6 (1), 37-52.

John, J. C. (2009). What is the difference in the quality of education provided by

Government and private schools in Tanzania? A comparative study. (Unpublished Thesis).

Johnson, R. B. \& Onwuegbuzie, A. J. (2004). Mixed methods research: A research paradigm whose time has come. Educational Researchers, 33 (7), 14-26.

Johnson, R. B., Onwuegbuzie, A. J. \& Turner, L. A. (2007). Toward a definition of a mixed method. Journal of Mixed Methods Research, 1 (2), 112-133.

Kieya, H. O. (2016). Factors influencing community participation in the implementation of murram road projects in Nyamira County, Kenya. (Unpublished Thesis). Nairobi University, Kenya.

Kimani, E. N. \& Kombo, D. K. (2011). An investigation of community participation in the development of schools and income generating projects in rural areas in Kenya. British Journal of Educational Research, 1 (1), 58-68.
Kothari, C. R. (2016). Research Methodology: Methods and Techniques (4th ed.). New Delhi, India: New Age International Publishers

Krueger, R. A. \& Casey, M. A. (2009). Focus groups: A Practical guide for applied research $\left(4^{\text {th }}\right.$ ed.). Thousand Oaks, CA: Sage.

Letea, H. (May 15, 2018). Teacher-Student ratio still a concern www.thecitizen.co.tz/news/

Lema, E., Omari, I., \& Rajani, R. (Eds.). (2005). Nyerere on education, Vol. II: Selected essays and speeches 1961-1997. Dar es salaam, Tanzania: Mwalimu Julius Nyerere Estate under the Trusteeship of The Mwalimu Nyerrere Foundation.

Lindsjo, K. (2017). "Everybody knows every child should be educated: The strive towards Universal Primary Education in Tanzania." Lundi University, Sweden.

López-Guzmán, T., Sánchez-Cañizares, S., \& Pavón, V. (2011). Community - based tourism in developing countries: A case study. Tourismos: An International Multidisciplinary Journal of Tourism, 6 (1), 69-84.

Makomelelo, P. \& Swai, H. (2013). Mwongozo wa Kuwajengea Uwezo Wajumbe wa Kamati za Shule HakiElimu kwa Ushirikiano na TRCC. Dar- es-salaam: Hakielimu.

Mansuri, V. \& Rao, G. (2004). Community-based and driven development: A critical review. World Bank Policy Research Working Paper. 3209, 1-77.

Mills, E. G. \& Gay, L. R. (2016). Education Research: Competencies for analysis and applications (11 $1^{\text {th }}$ Ed.). Essex, England: Pearson Education.

Ministry of Finance and Planning of The United Republic of Tanzania (2016). National Five Year Development Plan. 
Moos, R. H. (1979). Evaluating educational environment. London: Jossey-Bass.

Oni, S. S. (2015). Community participation in rural development: Catalyst for sustainable development efforts. Proceedings of INTCESS15- 2nd International Conference on Education and Social Sciences. Istambul

Mwaura, M. \& Ngugi, K. (2014). Factors affecting performance of Community-based Organization Projects in Kisii County, Kenya. International Journal of Social Sciences Management and Entrepreneurship, 1 (2), 51-67.

Nishimura, M., Ogawa, K., Sifuna, D. N., Chimombo, J., Kunje, P., Amphiah, J. G.,. . .Yamada, S. (2009). A Comparative Analysis of Universal Primary Education Policy in Ghana, Kenya, Malawi, and Uganda. Journal of International Cooperation in Education, 12 (1), 143-158.

Oyunge, A. M. (2015). Assessment of the provision of quality basic education in primary schools in Moshi Rural District, Tanzania. (Unpublished Thesis). Open University of Tanzania. Dar es Salaam. URL: http://repository.out.ac.tz/1224/

Phillips, R. \& Pittman, R. (Eds.). (2009). An introduction to community development. London: Routledge

Pradhan, M., Suryadarma, D., Beatty, A., Wong, M., Gaduh, A., Alishjabana, A. \& Artha, R. P. (2013). Improving educational quality through enhancing community participation: results from a randomized field experiment in Indonesia. Retrieved fromhttp://real.wharton.upenn.edu/ maisy/d ocuments/ School Committee_AEJA.

Rout, G. K. (2013). Community participation in Education: A changing pattern of educational administration in India. International Journal of Research Studies in Education, 2 (3), 85-98.

Phillips, R. \& Pittman, R. (Eds.). (2009). An introduction to community development. London: Routledge
Pradhan, M., Suryadarma, D., Beatty, A., Wong, M., Gaduh, A., Alishjabana, A. \& Artha, R. P. (2013). Improving educational quality through enhancing community participation: results from a randomized field experiment in Indonesia. Retrieved fromhttp://real.wharton.upenn.edu/ maisy/d ocuments/

School Committee_AEJA.

Rout, G. K. (2013). Community participation in Education: A changing pattern of educational administration in India. International Journal of Research Studies in Education, 2 (3), 85-98.

Robinson Jr., J. W. \& Green, G. P. (Eds.) (2011). Developing Communities. Introduction to community development: Theory, practice, and service-learning. Los Angeles: SAGE

Russell, K. A., Reimers, F., Mapp, K., Robotham, D., \& Warren, M. (2009). Community participation in schools in developing countries: Characteristics, methods and outcomes. Qualifying Paper. $\underline{\text { https://files.eric.ed.gov/fulltext/ED519214.p }}$ df

Schiele, J. J. H. (2005). Maggie Lena Walker and African American community development. Affilia, 20 (1), 21-38.

Spires, M., Shackleton. S., \& Cundill, C. (2014). Barriers to implementing planned

Community-based adaptation in developing countries: A systematic literature review. Journal of Climate and Development, 6 (3), 277-287.

Steele, F. I. (1973) Physical settings and organization development. Reading MA: AddisonWesley.

Swift-Morgan, J. (2006). What community participation in schooling means: Insights from Southern Ethiopia. Harvard Educational Review, 76(3), 339-368. 
Tan, A. (2009). Community development theory and practice: Bridging the divide between 'micro' and 'macro' level of social work. (Paper Presented) North American Association of Christians in Social Work (NACSW). Indianapolis, Indiana.

Turner, J. F. C. (2012). 2.0 Community Participation. (Report Chapter, pp.11-23), McGill University, Canada.

UNDP (2004) Sustainable Development Report on Africa: Resource managing land-based development. Paris: UNDP.

UNESCO (2015a). Education 2030: Equity and quality with a lifelong learning perspective. Paris, France.

UNESCO (2015b). Transforming our world: Literacy for sustainable development. Paris, France.

UNESCO (2016). Education for people and planet: Creating sustainable future for all. Global Education Monitoring Report. Paris, France.

URT (2015a). "Waraka wa elimu Namba 5 wa mwaka 2015” Kufuta ada kwa elimu ya secondary kidato cha kwanza mpaka cha nne kwa shule za umma na michango yote katika elimu msingi" Dar-es Salaam: Wizara ya Elimu, Sayansi na Teknologia, 21 Novemba, 2015.

URT (2015b). "Waraka wa elimuNamba 6 wa mwaka 2015” Kuhusu utekelezaji wa elimumsingi bila malipo" Dar-es Salaam: Wizara ya Elimu, Sayansi na Teknologia

URT (2016). Waraka wa Elimu Namba 3 wa Mwaka 2016 Kuhusu utekelezaji wa elimumsingi bila malipo. Dar es Salaam: Wizara ya Elimu, Sayansi na Teknolojia.

Yamada, S. (2014). Determinants of community participation: The tradition of local initiatives and the institutionalization of school management committees in Oromia Region, Ethiopia." Compare: A Journal of Comparative and International Education, 44 (2), 162-185.

Zohrabi, M. (2013). Mixed method research, instruments, validity, reliability and reporting findings. Theory and Practice in language Studies, 3 (2), 254-262. 